\title{
MENINGKATKAN KEMAMPUAN KONEKSI MATEMATIS MELALUI PEMBELAJARAN METAKOGNITIF (PENELITIAN TINDAKAN KELAS DI SEMESTER IV JURUSAN MATEMATIKA MATAKULIAH KALKULUS LANJUTAN LANJUTAN) TAHUN PELAJARAN 2014/2015.
}

\author{
INCREASING CAPACITY THROUGH LEARNING CONNECTIONS \\ MATHEMATICAL METACOGNITIVE (CLASS ACTION RESEARCH IN \\ SEMESTER IV DEPARTMENT OF MATHEMATICS CALCULUS \\ COURSE CONTINUED CONTINUED) YEARS OF STUDY 2014/2015.
}

\author{
Irmayanti \\ Pendidikan Matematika, Universitas Labuhanbatu, Indonesia \\ r.irmayanti@yahoo.com
}

\begin{abstract}
Abstrak
Tujuan dari penelitian ini untuk mengetahui peningkatan kemampuan koneksi matematika mahasiswa/i melalui pembelajaran metakognitif di Semester IV Jurusan Matematika Tahun Pelajaran 2014/2015. Penelitian ini merupakan Penelitian Tindakan Kelas (PTK). Subjek penelitian ini adalah mahasiswa/i semester IV matematika. Objek dalam penelitian ini adalah pembelajaran matematika dalam usaha peningkatan kemampuan koneksi matematika mahasiswa/i melalui pembelajaran metakognitif. Teknik pengumpulan data dengan cara: Observasi, tes, dan dokumen. Instrumen penelitian ini menggunakan: RPS, LKS, Tes dan Lembar Observasi. Penelitian tindakan kelas ini dilaksanakan dalam 2 siklus, yang masing-masing siklus terdiri dari tahap perencanaan, pelaksanaan, pengamatan dan refleksi. Hasil penelitian menunjukkan bahwa untuk untuk siklus I untuk indikator 1, indikator 2, dan indikator 3 berdasarkan kategori Sangat Kurang (SK), Kurang (K), Cukup (C), Baik (B) dan Sangat Baik (SB) berturut-turut ada sebesar 63,88\%, 77,76\%, 80,55\%, 63,88\%, dan 5,54\%. Setelah dilakukan pemberian tindakan dengan model pembelajaran Metakognitif, banyak mahasiswa/i yang berhasil meningkatkan kemampuan koneksi matematika pada akhir siklus II, untuk indikator 1, 2 dan 3 kategori Sangat Kurang (SK), Kurang (K), Cukup (C), Baik (B) dan Sangat Baik (SB) berturut-turut ada sebesar 13,88\%, 44.43\%, 33,32\%, 116,65\%, dan 91,65\%. Dari penelitian ini dapat diperoleh simpulan bahwa melalui pembelajaran Metakognitif dapat meningkatkan kemampuan koneksi mahasiswa/i semester IV matematika Universitas Labuhanbatu.
\end{abstract}

Kata Kunci: Kemampuan Koneksi Matematika, Pembelajaran Metakognitif.

\begin{abstract}
This study was conducted to determine the effect of household waste to the environment in terms of aspects of biology at the housing complex kel housekeeping earth. nevertheless compass excl. southern shoreline. This research is a field (Field Research) is a research .Populasi residents handle garbage Complex Graha Pertiwidalam citizens. Samples were done by using stratified random sampling. Untuk collect the necessary data in this study, the data collection tools used, ie observation, interviews, and Library Research.Teknik data collectors that researchers use is to conduct interviews with entrepreneurs
\end{abstract}


as a developer Complex Graha Pertiwi the data collected from the field study will be presented systematically. The results of the research, that rubbish in Housing Complex Graha Pertiwi derived from household waste from residents who live in the complex. The type of waste that is often seen is composed of organic waste and garbage in the complex non organik. Setiap day Graha Pertiwi inmates on average to dispose of waste ranging from $1 \mathrm{~kg} /$ perharinya.Kesadaran high community waste management is big enough where their garbage stacked on the front page house and burned, so that the waste could not accumulate too lama.Kendala faced and penanggulangannyamasih efforts in creating public awareness of cleanliness lingkungan.Hal is seen from a habit of throwing garbage on tempatnya.Persepsi community about waste management is still concentrated in the government, whereas hygiene problem is a shared responsibility between the public and the government, the limited space for the collection and final disposal, as well as limited transportation funds rubbish. While a pile of garbage is increasing day by day.

Keywords: Household Waste, Graha Pertiwi

\section{PENDAHULUAN}

Pengertian pendidikan yang tercantum dalam UU Sisdiknas Tahun 2003 adalah usaha sadar dan terencana untuk mewujudkan suasana belajar dan proses pembelajaran agar peserta didik secara aktif mengembangkan potensi dirinya untuk memiliki kekuatan spiritual keagamaan, kecerdasan, akhlak mulia serta keterampilan, pengendalian diri, kepribadian, kecerdasan, akhlak mulia serta keterampilan yang diperlukan dirinya, masyarakat, bangsa dan negara. Secara implisit dapat dimaknai bahwa peserta didik atau mahasiswa/i adalah orang yang sudah memiliki potensi dalam dirinya dan perlu dikembangkan.

Matematika merupakan salah satu mata pelajaran yang harus diajarkan di sekolah yang tentu memiliki peran penting dalam mencapai tujuan pendidikan, karena matematika membekali peserta didik untuk berpikir logis, analitis, sistematis, kritis, dan kreatif. Adapun tujuan pendidikan matematika sebagaimana yang terdapat dalam KTSP yaitu agar peserta didik memiliki kemampuan sebagai berikut :

1. Memahami konsep matematika, menjelaskan keterkaitan antara konsep dan mengaplikasikan konsep atau algoritma, secara luwes, akurat, efisien, dan tepat dalam menyelesaikan masalah.

2. Menggunakan penalaran pada pola sifat, melakukan manipulasi matematika dalam membuat generalisasi, menyusun bukti, atau menjelaskan gagasan dan pernyataan matematika.

3. Memecahkan masalah yang meliputi kemampuan memahami masalah, merancang model matematika, menyelesaikan model dan menafsirkan solusi yang diperoleh. 
4. Mengomunikasikan gagasan dengan simbol, tabel, diagram, atau media lain untuk memperjelas keadaan atau masalah.

5. Memiliki sikap menghargai kegunaan matematika dalam kehidupan, yaitu memiliki rasa ingin tahu, perhatian, dan minat dalam mempelajari matematika, serta sikap ulet dan percaya diri dalam pemecahan masalah (Depdiknas, 2006:43).

Tujuan yang ideal tersebut pada kenyataannya tidak selalu mudah dicapai oleh sekolah. Sebagai gambaran peneliti selaku dosen matematika semester IV matakuliah Kalkulus Lanjutan, bahwa memang proses belajar mengajar sudah cukup optimal, tetapi mahasiswa/i masih kesulitan dalam menyelesaikan soal terkait menuliskan masalah kehidupan sehari-hari ke dalam bentuk model matematika. Mahasiswa/i juga masih kesulitan dalam menghubungkan antar obyek dan konsep dalam matematika. Selain itu, mahasiswa/i juga masih kesulitan dalam menentukan rumus apa yang akan dipakai jika dihadapkan pada soal-soal yang berkaitan dengan masalah kehidupan sehari-hari.

Berdasarkan hal di atas, peneliti melakukan observasi dan wawancara kepada mahasiswa/i terhadap masalah yang telah dikemukakan. Peneliti melihat bahwa mahasiswa/i kesulitan dalam menghubungkan antar konsep yang sebelumnya telah diketahui oleh mahasiswa/i dengan konsep baru yang akan mahasiswa/i pelajari. Kesulitan-kesulitan mahasiswa/i dalam belajar Kalkulus Lanjutan yang telah disebutkan di atas merupakan unsurunsur kemampuan koneksi matematika. Sehingga dari hasil wawancara dan hasil observasi menunjukkan adanya kemampuan koneksi matematika mahasiswa/i semester IV Universitas Labuhanbatu yang masih belum optimal.

Kemampuan koneksi matematika mahasiswa/i semester IV Universitas Labuhanbatu yang masih belum optimal tidak sesuai dengan pendapat NCTM (2000: 29) dalam Principles and Standards for School Mathematics, yang menyatakan bahwa standar proses dalam pembelajaran matematika yaitu kemampuan pemecahan masalah (problem solving), kemampuan penalaran (reasoning), kemampuan komunikasi (communication), kemampuan membuat koneksi (connection), dan kemampuan representasi (representation). Dari pendapat di atas, kemampuan mahasiswa/i membuat koneksi merupakan salah satu dari standar proses dalam pembelajaran matematika. Oleh karena itu, dalam pembelajaran matematika siswa perlu mempunyai kemampuan koneksi matematika. 
Untuk mengoptimalkan kemampuan koneksi matematika khususnya pada mahasiswa/i semester IV Universitas Labuhanbatu, perlu untuk dicarikan solusi. Solusinya adalah dengan menggunakan model pembelajaran metakognitif. Kemampuan metakognitif merupakan bagian dari apa yang disebut "proses eksekutif" atau "strategi metakognitif". Kemampuan metakognitif ini meliputi aktivitas seperti perhatian, persepsi, orientasi/monitoring pengertian persyaratan tugas, merencanakan langkah-langkah yang diambil untuk proses tugas, merespon/mengecek dan mengatur proses kognitif jika terjadi kegagalan, dan mengevaluasi hasil proses. Kemampuan metakognitif sebagai bagian dari proses pengaturan diri, kemampuan mengontrol proses berpikir diri sendiri ada dalam tiap tahapan dalam problem solving. Pada tiap tahap (tahap orientasi, tahap organisasi, tahap eksekusi, dan tahap verifikasi) dalam menyelesaikan masalah mahasiswa/i harus memonitor berpikirnya sekaligus membuat keputusan-keputusan dalam melaksanakan tahapan yang dipilihnya itu agar masalah dapat terselesaikan dengan baik bahkan pada tahap akhir, siswa harus mempertanyakan kembali atas jawaban yang dibuatnya apakah jawabannya benar-benar telah sesuai dan apakah memungkinkan ada cara lain yang lebih efektif dalam menghubungkan dan menyelesaikan masalah yang diberikan.

Dari uraian di atas, dapat disimpulkan bahwa betapa pentingnya seorang dosen yang visioner dan mampu mengelola proses belajar mengajar secara efektif dan inovatif, sehingga dapat mengembangkan potensi yang ada dalam diri mahasiswa/i. Untuk itu, diperlukannya perubahan strategi dan model pembelajaran yang sedemikian rupa memberikan nuansa yang menyenangkan bagi guru dan mahasiswa/i, kebermaknaan materi bagi mahasiswa/i.

Berdasarakan uraian di atas, penulis tertarik untuk menulis tentang Meningkatkan Kemampuan Koneksi Matematis Pada Matakuliah Kalkulus Lanjutan Melalui Pembelajaran Metakognitif di Semester IV Jurusan Matematika Universitas Labuhanbatu.

Penelitian ini bertujuan untuk mengetahui peningkatan kemampuan koneksi matematika mahasiswa/i melalui pembelajaran metakognitif di Semester IV Jurusan Matematika Tahun Pelajaran 2014/2015.

\section{METODE}

Penelitian ini adalah penelitian tindakan kelas (PTK). Tindakan yang diberikan adalah menggunakan model pembelajaran metakognitif dengan tahapan-tahapan perencanaan, pelaksanaan tindakan, observasi, dan refleksi. 
Subjek dalam penelitian ini adalah mahasiswa/i semester IV Jurusan Matematika pada matakuliah Kalkulus Lanjutan Tahun Pelajaran 2014/2015 dengan jumlah 36 orang dengan kemampuan yang heterogen. Objek dalam penelitian ini adalah pembelajaran matematika dalam usaha peningkatan kemampuan koneksi matematika mahasiswa/i melalui pembelajaran metakognitif.

Instrumen yang digunakan dalam penelitian ini adalah :

a. Lembar observasi, untuk memperoleh data tentang kondisi pelaksanaan model pembelajaran Metakognitif di kelas.

b. Tes hasil belajar, untuk memperoleh data hasil belajar mahasiswa/i setelah diterapkan model pembelajaran Metakognitif.

c. Jurnal refleksi diri, untuk memperoleh data tentang refleksi diri.

\section{HASIL PENELITIAN}

a) Sebelum Penelitian

Berdasarkan deskripsi kegiatan penelitian pra tindakan kelas, terdapat masalah kemampuan koneksi matematika mahasiswa/i yang masih kurang, terlihat dari contoh pengerjaan mahasiswa/i. Dari hasil pekerjaan mahasiswa/i, terlihat bahwa mahasiswa/i belum mampu menuliskan diketahui dan ditanya, mahasiswa/i belum mampu untuk membuat model matematika, dan mahasiswa/i belum mampu untuk menuliskan konsep-konsep yang mendasari jawaban, dan mahasiswa/i belum mampu menuliskan hubungan antar obyek dan konsep matematika. Dari hasil tersebut, terlihat masih lemahnya kemampuan koneksi matematika mahasiswa/i, padahal kemampuan koneksi (connection) merupakan salah satu dari lima kemampuan standar yang harus dimiliki mahasiswa/i dalam belajar matematika (NCTM, 2000: 29). Data hasil tes kemampuan koneksi matematika mahasiswa/i sebelum dilaksanakan pemberian tindakan menggunakan model pembelajaran Metakognitif adalah sebagai berikut:

Tabel 4.1 Kemampuan Koneksi Matematika Sebelum Pemberian Tindakan

No. Indikator $\quad$ Persentase Jumlah Siswa dalam Kategori (\%)




\section{$\begin{array}{lllll}\text { SK } & \text { K } & \text { C } & \text { B } & \text { SB }\end{array}$}

1 Menuliskan masalah kehidupan

$\begin{array}{lllll}63,89 & 25 & 8,33 & 0 & 2,78\end{array}$

Sehari-hari ke dalam bentuk

model matematika

2. Menuliskan konsep yang mendasar

$36,11 \quad 16,67 \quad 19,44 \quad 27,78 \quad 0$

jawaban

3. Menuliskan hubungan antar obyek $\quad \begin{array}{lllll}80,55 & 13,89 & 2,78 & 2,78 & 0\end{array}$

dan konsep matematika

Keterangan :

SK = Sangat Kurang $\quad \mathrm{B}=$ Baik $\quad \mathrm{K}=$ Kurang

$\mathrm{SB}=$ Sangat Baik $\quad \mathrm{C}=$ Cukup

Dari hasil tes sebelum pemberian tindakan pada tabel 4.1 menunjukkan adanya masalah pada kemampuan koneksi matematika mahasiswa/i. Masalah kemampuan koneksi matematika mahasiswa/i yang masih belum optimal.

Berdasarkan hasil pretes atau pra tindakan kelas pada tabel 4.1 di atas, terlihat bahwa mahasiswa/i belum memiliki kemampuan koneksi matematika. Hal ini juga diperkuat dengan persentase kategori kemampuan koneksi matematika mahasiswa/i per indikator pada tabel 4.1.

b) Hasil Penelitian Siklus I

Berdasarkan deskripsi pelaksanaan penelitian tindakan kelas siklus I, terdapat beberapa masalah pada fase yang terdapat pada model pembelajaran Metakogtitif, masalah terdapat pada fase organisasi, fase eksekusi, dan fase verifikasi. Pada fase organisasi, mahasiswa/i masih kesulitan dalam menuliskan diketahui, ditanyakan, membuat model matematika dari suatu masalah kehidupan sehari-hari, menuliskan konsep apa saja yang digunakan mahasiswa/i dalam menjawab soal, dan menuliskan hubungan antar konsep dalam menjawab soal.

Pada fase eksekusi, masalah yang ditemui adalah mahasiswa/i masih malu-malu dan takut salah dalam mempresentasikan hasil diskusi kelompok, masih ada beberapa mahasiswa/i yang 
mengobrol dan sibuk sendiri selama presentasi berlangsung. Pada fase verifikasi, masalah yang ditemui adalah kurangnya waktu dalam mengkoreksi jawaban bersama-sama, sehingga fase verifikasi dilanjutkan setelah pelajaran berakhir, dan guru memberikan simpulan setelah pengkoreksian tersebut selesai.

Berdasarkan hasil tes siklus I yang menunjukkan adanya peningkatan kemampuan koneksi matematika mahasiswa/i. Peningkatan tersebut akan diperjelas pada tabel 4.2.

Tabel 4.2. Peningkatan Kemampuan Koneksi Matematika dari sebelum Pemberian Tindakan sampai Akhir Siklus I

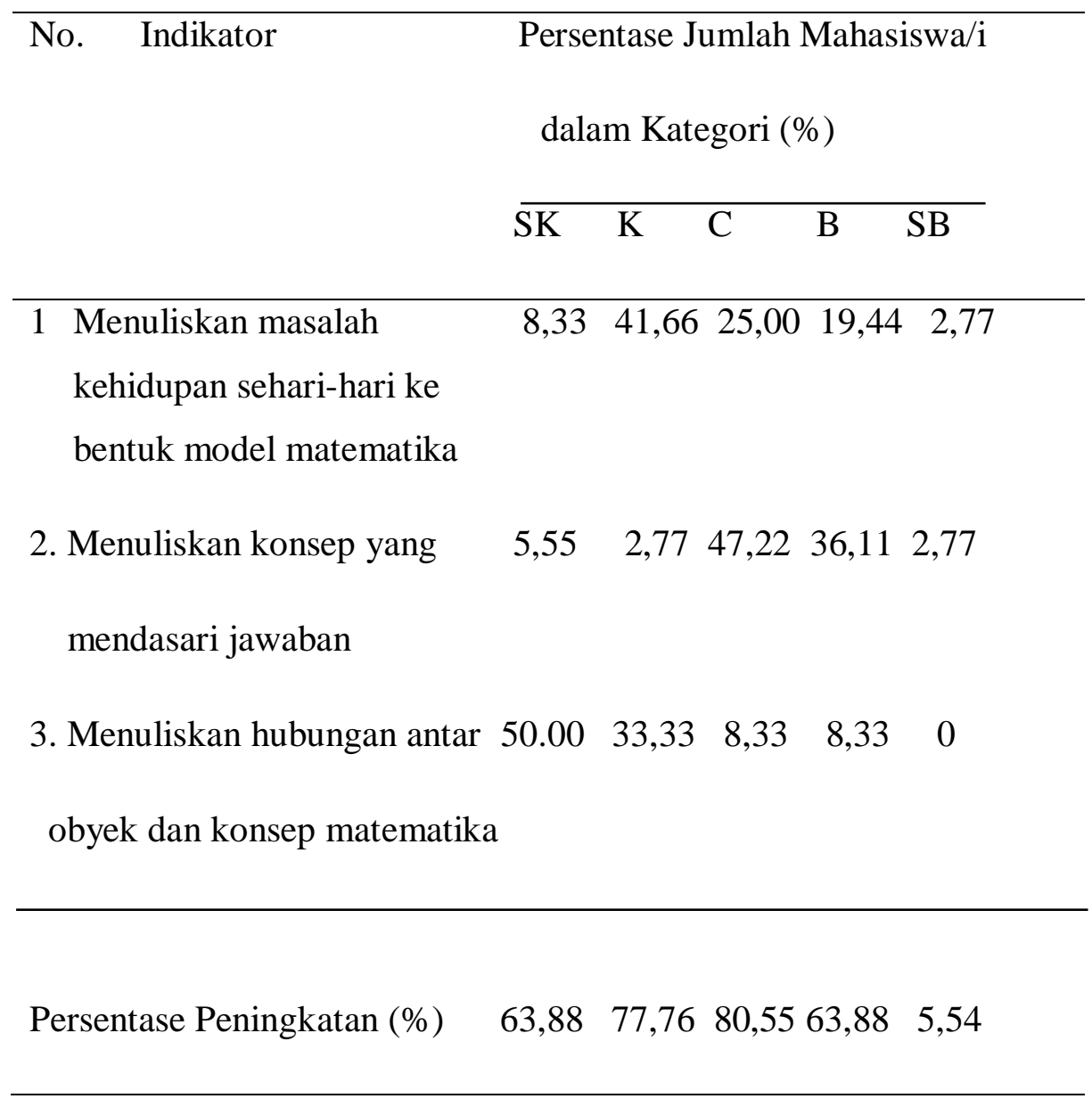

Keterangan :

SK = Sangat Kurang $\quad \mathrm{B}=$ Baik $\quad \mathrm{K}=$ Kurang

$\mathrm{SB}=$ Sangat Baik $\quad \mathrm{C}=$ Cukup 
Berdasarkan tabel 4.2 diatas banyaknya mahasiswa/i yang mengalami peningkatan kemampuan koneksi matematika dari sebelum pemberian tindakan sampai akhir siklus I untuk indikator 1, indikator 2, dan indikator 3 berdasarkan kategori Sangat Kurang (SK), Kurang (K), Cukup (C), Baik (B) dan Sangat Baik (SB) berturut-turut ada sebesar 63,88\%, 77,76\%, 80,55\%, $63,88 \%$, dan $5,54 \%$.

c) Hasil Penelitian Siklus II

Berdasarkan deskripsi pelaksanaan penelitian tindakan kelas siklus II, masalah-masalah yang ada pada fase organisasi, fase eksekusi, dan fase verifikasi dalam pemberian tindakan siklus I sudah diperbaiki. Perbaikan-perbaikan yang dilakukan pada pemberian tindakan siklus II dalam tiap fase tersebut ternyata dapat mengatasi masalah-masalah yang muncul pada pemberian tindakan siklus I. Dapat disimpulkan bahwa masalah-masalah tersebut sudah dapat diatasi pada pemberian tindakan siklus II. Setelah masalah-masalah yang ada pada pemberian tindakan siklus I dapat diatasi. Berdasarkan hasil tes siklus II menunjukkan adanya peningkatan kemampuan koneksi matematika mahasiswa/i. Peningkatan tersebut akan diperjelas pada tabel 4.3.

Tabel 4.3. Peningkatan Kemampuan Koneksi Matematika Siklus II

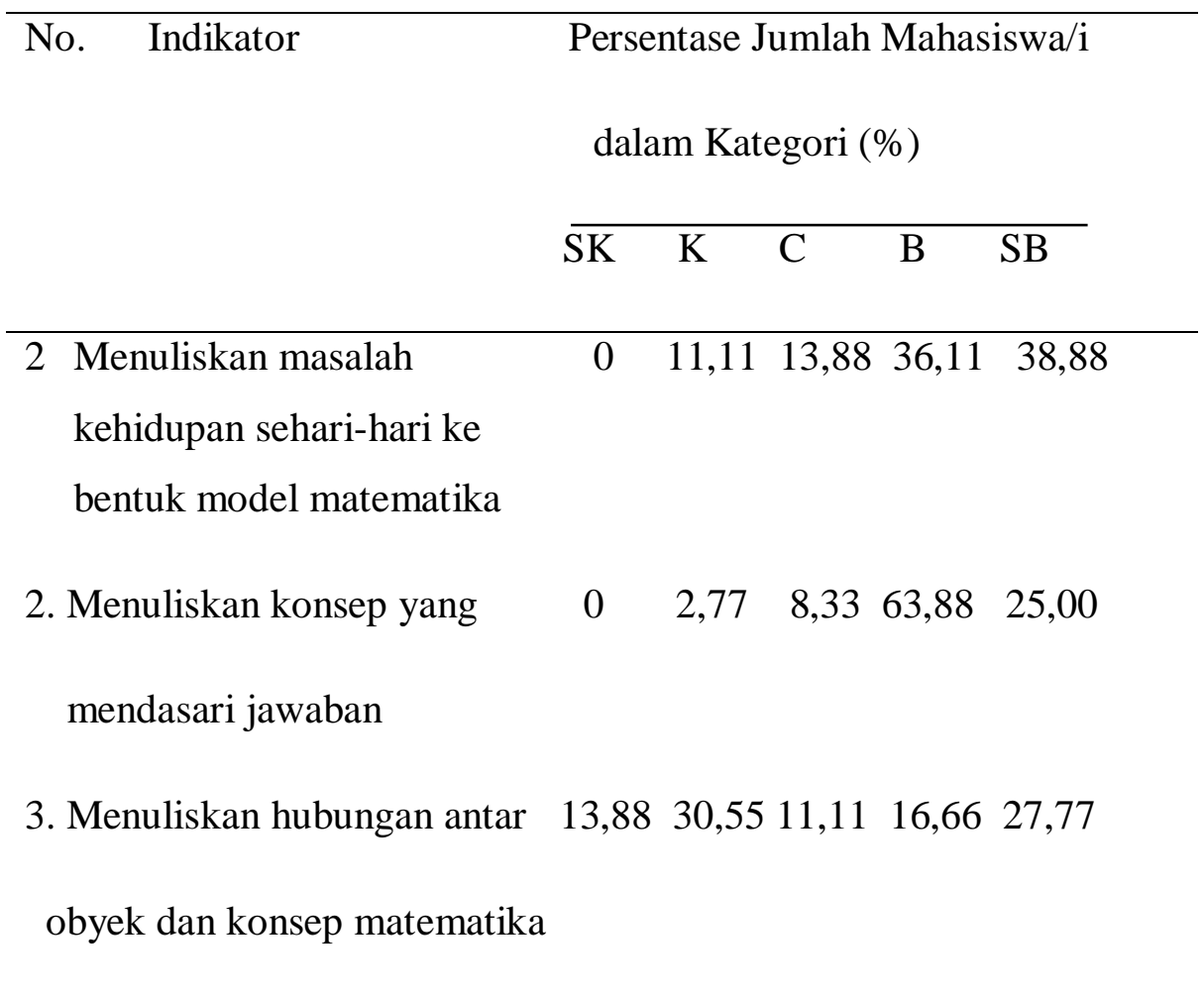


Persentase Peningkatan (\%) $\quad 13,88 \quad 44,4333,32$ 116,65 91,65

Keterangan :

SK $=$ Sangat Kurang $\quad \mathrm{B}=$ Baik $\quad \mathrm{K}=$ Kurang

$\mathrm{SB}=$ Sangat Baik $\quad \mathrm{C}=$ Cukup

Berdasarkan tabel 4.3 diatas banyaknya mahasiswa/i yang mengalami peningkatan kemampuan koneksi matematika dari akhir siklus I sampai akhir siklus II untuk indikator 1, indikator 2, dan indikator 3, berdasarkan kategori Sangat Kurang (SK), Kurang (K), Cukup (C), Baik (B) dan Sangat Baik (SB) berturut-turut ada sebesar 13,88\%, 44,43\%, 33,36\%, 116,65\%, dan $91,65 \%$.

\section{PEMBAHASAN}

Berdasarkan deskripsi pelaksanaan tindakan kelas siklus I dan deskripsi pelaksanaan tindakan kelas siklus II, serta data hasil tes kemampuan koneksi matematika mahasiswa/i semester IV matematika, akan dibahas hal-hal yang menjadi masalah pada pembelajaran dengan menggunakan model pembelajaran Metakognitif yang mempunyai tahapan-tahapan Orientasi, Organisasi, Eksekusi, dan Verifikasi.

a) Pelaksanaan Tindakan Kelas Siklus I

Adanya masalah kemampuan koneksi matematika pada mahasiswa/i, ditunjukkan dengan masih belum optimalnya hasil tes kemampuan koneksi matematika pada tes pra tindakan atau pretes, terlihat pada tabel 4.1. Peneliti melakukan pemberian tindakan pada siklus I dengan menggunakan model pebelajaran Metakognitif. Peneliti memilih model pembelajaran Metakognitif, karena model pembelajaran Metakognitif memuat langkah-langkah: Orientasi, Organisasi, Eksekusi, dan Verifikasi. Dimana langkah-langkah tersebut memungkinkan untuk 
mengembangkan kemampuan koneksi matematika mahasiswa/i. Hal ini sudah disinggung tentang keterkaitan antara model pembelajaran Metakognitif dengan kemampuan koneksi matematika. Masalah-masalah yang ditemui pada pemberian tindakan siklus I adalah pada fase organisasi, fase eksekusi, dan fase Verifikasi.

Pada fase organisasi, sudah dijelaskan sebelumnya terdapat beberapa permasalahan yang mahasiswa/i hadapi. Di antaranya adalah kesulitan mahasiswa/i dalam menemukan rumus, menyelesaikan soal koneksi matematika yang terdapat pada LKS. Mahasiswa/i masih kesulitan dalam menuliskan diketahui, ditanyakan, dan membuat model. Mahasiswa/i juga masih kesulitan dalam menuliskan konsep yang mendasari jawaban. Dan mahasiswa/i masih kesulitan dalam menuliskan hubungan antar obyek dan konsep matematika. Namun kesulitan-kesulitan ini didiskusikan oleh mahasiswa/i bersama teman satu kelompok, sehingga mahasiswa/i mampu mengembangkan pemikirannya dalam wadah diskusi yang ada pada fase eksekusi model pembelajaran Metakognitif. Hal ini sesuai dengan pendapat Vygotsky tentang konstruktivisme sosial, yang menyatakan bahwa "Interaksi sosial memainkan peran penting dalam perkembangan intelektual mahasiswa/i”. Hal ini juga sesuai dengan pendapat Sunaryo (2000, 107). yang menyatakan bahwa diskusi kelompok bertujuan untuk memberi kesempatan peserta untuk saling mengemukakan pendapat dalam mengenal dan memecahkan problema.

Pada fase eksekusi, masalah yang ditemui adalah masih banyak mahasiswa/i yang rasa percaya dirinya belum muncul untuk mempresentasikan hasil diskusi. Ada beberapa mahasiswa/i yang masih mengobrol selama presentasi berlangsung. Menurut pendapat Hakim (2002, 137) cara untuk menumbuhkan rasa percaya diri mahasiswa/i antara lain adalah guru harus berperan aktif. Oleh karena itu pada pertemuan berikutnya guru berperan lebih aktif dalam memotivasi mahasiswa/i untuk percaya diri mempresentasikan hasil dikusi mahasiswa/i. Sehingga mahasiswa/i sudah muncul rasa percaya dirinya untuk mempresentasikan hasil diskusi di depan kelas. Pada mahasiswa/i yang masih mengobrol, guru sudah berusaha menegur namun belum nampak hasilnya.

Pada fase verifikasi, masalah yang ditemui adalah masalah waktu. Tidak cukupnya waktu mengevaluasi pembelajaran pada pertemua pertama dan kedua menyebabkan fase verifikasi kurang maksimal, sehingga waktu mahasiswa/i untuk mengevaluasi hasil pekerjaan mahasiswa/i juga kurang optimal. Padahal fase verifikasi merupakan suatu fase penting. Sesuai dengan 
pendapat Roestiyah (2001: 134), evaluasi merupakan sesuatu yang penting untuk mahasiswa/i karena dapat menumbuhkan semangat kerja yang lebih baik, dan meningkatkan hasrat belajar.

Dari pendapat tersebut, kita mengetahui bahwa pentingnya evaluasi adalah untuk meningkatkan hasrat belajar mahasiswa/i, mahasiswa/i yang mendapat hasil tidak memuaskan terus belajar untuk memperbaiki hasil pekerjaan selanjutnya, sedangkan untuk mahasiswa/i yang sudah mendapatkan hasil yang memuaskan, mahasiswa/i terus belajar untuk mempertahnkan hasil belajarnya atau bahkan meningkatkan hasil belajarnya pada tes selanjutnya.

Berdasarkan tabel 4.2, banyak mahasiswa/i yang mengalami peningkatan kategori untuk indikator 1, indikator 2, indikator 3 berdasarkan kategori Sangat Kurang (SK), Kurang (K), Cukup (C), Baik (B) dan Sangat Baik (SB) berturut-turut ada sebesar 63,88\%, 77,76\%, 80,55\%, $63,88 \%$, dan 5,54\%. Mahasiswa/i yang mengalami peningkatan kategori Baik (B) dan Sangat Baik (SB) untuk indikator 1, 2 dan 3 belum memenuhi indikator keberhasilan yaitu kurang dari $65 \%$. Dengan demikian pembelajaran belum mengalami peningkatan sesuai yang diharapkan sesuai indikator keberhasilan.

Belum tercapainya keberhasilan besar kemungkinan karena belum adanya petunjuk membuat model matematika pada LKS, dosen mengatakan secara lisan untuk mahasiswa/i membuat model matematika untuk menjawab soal, tetapi tidak tertulis pada LKS. Keberhasilan mahasiswa/i membuat model matematika, dapat berdampak pada kemampuan mahasiswa/i menuliskan konsep-konsep yang digunakan mahasiswa/i dalam menjawab soal (Indikator 2), dan kemampuan mahasiswa/i untuk menuliskan hubungan antar obyek dan konsep matematika dalam menjawab soal (Indikator 3). Hasil tes kemampuan koneksi matematika mahasiswa/i pada siklus I belum optimal mungkin dikarenakan masih belum optimalnya fase organisasi, fase aksekusi, dan fase everifikasi model pembelajaran Metakognitif yang dilakukan pada pemberian tindakan siklus I. Dengan demikian penelitian akan dilanjutkan ke siklus II dengan perbaikanperbaikan pada fase organisasi, fase aksekusi, dan fase everifikasi model pembelajaran Metakognitif agar pemberian tindakan siklus II pada mahasiswa/i dapat lebih optimal, dan dapat meningkatkan hasil tes kemampuan koneksi matematika mahasiswa/i di akhir siklus II.

b) Pelaksanaan Tindakan Kelas Siklus II

Masalah kemampuan koneksi matematika belum teratasi secara optimal. Meskipun sudah ada peningkatan, namun belum memenuhi indikator keberhasilan pada siklus I. Maka penelitian 
dilanjutkan ke siklus II dengan pemberian tindakan yang sama seperti pada pemberian tindakan siklus I dengan menggunakan model pembelajaran Metakognitif dengan langkah-langkah sebagai berikut: orientasi, organisasi, eksekusi dan verifikasi. Walaupun pemberian tindakan sama seperti pada pemberian tindakan siklus I, namun adanya perbaikan terutama pada fase organisasi dan eksekusi yang dirasa peneliti masih kurang optimal pada siklus I.

Pada fase organisasi, perbaikan dilakukan pada LKS. Petunjuk pada soal yang tercantum dalam LKS, sudah tertulis jelas membuat model matematika untuk menjawab soal. Dengan petunjuk menjawab soal yang jelas, mahasiswa/i fokus pada petunjuk-petunjuk yang sudah diberikan. Sehingga sudah adanya perbaikan hasil pekerjaan mahasiswa/i pada pertemuaan ketiga dan keempat.

Pada fase eksekusi, untuk mengatasi mahasiswa/i yang masih mengobrol, guru mencoba menegur secara verbal, dengan mendekati mahasiswa/i tersebut. Guru mengatakan bahwa presentasi ini berguna untuk kalian dalam memahami materi pelajaran. Guru mencoba menumbuhkan motivasi mahasiswa/i tersebut. Guru juga memberikan nasihat agar mahasiswa/i dapat menghargai orang lain yang sedang berbicara. Cara yang guru gunakan sesuai dengan cara yang dikemukakan oleh Winkel dalam bukunya yag berjudul Psikologi Pengajaran. Menurut Winkel (2004: 434), teguran verbal sambil mendekati mahasiswa/i tertentu, dengan berbicara dengan suara kecil,sehingga paling-paling dua-tiga mahasiswa/i mendengar teguran itu. Menegur seseorang di hadapan umum dengan bersuara keras mengandung resiko, yaitu mahasiswa/i yang ditegur akan merasa bangga karena mendapat tanggapan positif dari teman sekelas "telah berhasil membuat guru marah". Teguran yang diberikan oleh guru ternyata efektif untuk membuat mahasiswa/i tidak ribut kembali. Sehingga pada pertemuan berikutnya, mahasiswa/i sudah tidak ribut kembali, mahasiswa/i fokus dalam memperhatikan presentasi. Mahasiswa/i aktif, kelas terkondisi dengan baik, presentasi berjalan lancar.

Berdasakan tabel 4.3, banyak mahasiswa/i yang mengalami peningkatan kategori untuk indikator 1, indikator 2, indikator 3 berdasarkan kategori Sangat Kurang (SK), Kurang (K), Cukup (C), Baik (B) dan Sangat Baik (SB) berturut-turut ada sebesar 13,88\%, 44.43\%, 33,32\%, 116,65\%, dan 91,65\%. Peningkatan kemampuan koneksi matematika mahasiswa/i pada ketiga indikator besar kemungkinan karena perbaikan-perbaikan yang sudah dilakukan pada siklus II, perbaikan pada fase exploration, fase explanation, dan pengoptimalan pada fase evaluation model pembelajaran Metakognitif. Karena banyak mahasiswa/i yang mengalami peningkatan 
kemampuan koneksi matematika pada kategori Baik (B) dan Sangat Baik (SB) untuk indikator 1, 2 dan 3 sudah lebih dari 85\%, maka dapat disimpulkan bahwa indikator keberhasilan pada siklus II sudah terpenuhi. Dapat dikatakan pemberian tindakan dengan model pembelajaran Metakognitif dapat meningkatkan kemampuan koneksi matematika mahasiswa/i semester IV Universitas Labuhanbatu.

\section{KESIMPULAN}

Setelah dilaksanakan pembelajaran matematika dengan model pembelajaran Metakognitif di semester IV Universitas Labuhanbatu, kemampuan koneksi matematika mahasiswa/i mengalami peningkatan. Hal ini ditunjukkan dengan kemampuan koneksi matematika mahasiswa/i sebelum pemberian tindakan, untuk siklus I untuk indikator 1, indikator 2, dan indikator 3 berdasarkan kategori Sangat Kurang (SK), Kurang (K), Cukup (C), Baik (B) dan Sangat Baik (SB) berturut-turut ada sebesar 63,88\%, 77,76\%, 80,55\%, 63,88\%, dan 5,54\%. Setelah dilakukan pemberian tindakan dengan model pembelajaran Metakognitif, banyak mahasiswa/i yang berhasil meningkatkan kemampuan koneksi matematika pada akhir siklus II, untuk indikator 1, 2 dan 3 kategori Sangat Kurang (SK), Kurang (K), Cukup (C), Baik (B) dan Sangat Baik (SB) berturut-turut ada sebesar 13,88\%, 44.43\%, 33,32\%, 116,65\%, dan 91,65\%.

Berdasarkan hasil penelitian yang dilakukan maka disarankan walaupun sudah adanya peningkatan kemampuan koneksi matematika mahasiswa/i, namun masih ada mahasiswa/i yang berada pada kategori kurang dan sangat kurang. Oleh karena itu, kemampuan koneksi matematika mahasiswa/i masih dapat ditingkatkan lagi dengan lebih mengoptimalkan fase organisasi. Fase eksekusi pada model pembelajaran Metakognitif dapat lebih dioptimalkan dengan memperbaharui LKS yang merupakan alat untuk memfasilitasi fase eksekusi.

\section{DAFTAR PUSTAKA}

Depdiknas. 2006. "Panduan Pengembangan Silabus Mata Pelajaran Matematika untuk SMP”. Jakarta: Ditjen Dikdasmen.

Derry, dkk. (1993). Cognition. New York . Harcount Brace Publishers.

Fauzi, A. (2009). Penerapan Kemampuan Metakognitif dalam Pemecahan Masalah. 
Irmayanti:Meningkatkan Kemampuan Koneksi Matematis....................

Foong, P.Y. (2002). Using Short Opend-Ended Mathematics Questions to Promote Thinking and Undestanding. National Institute of Education, Singapore [Online] Provided : http:/www.math.unipa.it/ grim/SiFoong. PDF

Hakim, T. 2002. Pengaruh Pembelajaran Metakognitif Terhadap Pemahaman dan Kemampuan Komunikasi Matematis Mahasiswa/i SMK. Tesis tidak diterbitkan. Medan: Sekolah Pascasarjana Universitas Negeri Medan

Nindiasari. (2004).Meningkatkan Kemampuan Komunikasi Matematika Melalui Pembelajaran Metakognitif di Kelas VII SMP. Skripsi Tidak Diterbitkan

Sunaryo. 2000. Model Pembelajaran Terpadu. Jakarta: Bumi Aksara 